\title{
618
}

THE JOURNAL OF THEOLOGICAL STUDIES

passage (pp. $40 \mathrm{ff}$. of this edition; Delarue I $8 \mathrm{I}^{6} \mathrm{~L}_{8 \mathrm{I}} \mathrm{7}^{\mathrm{a}}$ ). Megethius the Marcionite says it is clear from the fact of Christians being persecuted, that they do not belong to the Demiurge, but to another God; for the Scripture says 'the king's heart is in the hand of God.' 'It is clear therefore that $\delta$ ins reviocess beós himself persecuted us, from his baving the hearts of the kings in his hands.' Zahn considers that Rufinus preserves the original answer, written during a time of persecution, about 300 A.D., and that the Greek was revised between $33^{\circ}$ and 337 A.D., to suit the eircumstances of the time after Constantine had professed Christianity. At a later time a reviser went to work trying to better matters in the epilogue, where the Greek text got into hopeless confusion owing to several pages being misplaced in an ancestor of our MSS. In many other passages too, Rufinus, as we might expect, no doubt found a better text than the one we now possess, though it was not free from corruptions. As he allowed himself a very free hand in translating, especially in the longer speeches, and not only avoided difficulties, but occasionally tried to improve the argument, it is often difficult to feel sure that he really had a better text than ours. An unprejudiced reader is forced to the conclusion that the composer of the Dialogue was quite capable of writing illogical nonsense; its occurrence, therefore, is no proof that the text is corrupt, even if Rufinus' version gives a better sense.

Bakhuyzen has made full use of all the materials available, and has reconstructed the original text with great critical acumen, as far as it is possible to do so; but in many cases the translation of Rufinus merely suggests that the Greek text is corrupt without affording any means of setting it rigbt. Little further, it would appear, can be done unless better Greek MSS should be discovered.

P. Mordaunt Barnard.

\section{DR. MOBERLY ON ATONEMENT AND PERSONALITY.}

Atonement and Personality, by R. C. MoBerLy, D.D. (London: John Murray, Igor.)

There have been many indications lately that the problem of Personality is beginning to occupy the foremost place in religious philosophy. At present, it divides idealists into two camps, as appears in the very interesting discussion between four American professors which has been recently published under the title of The Conception of God. 'The antithesis between Monistic Idealism and Ethical Individualism,' says Professor Royce, 'reveals a very deep and instructive antinomy of reason ; an antinomy which we must all recognise before we can hope 
to solve it or transcend it.' In this country 'Ethical Individualism' (or Pluralism) has lately found an able exponent in Professor Ward, who follows Lotze in postulating a multitude of real and independent spirits, to whose existence such metaphors as 'separate,' 'incompenetrable,' 'mutually exclusive,' may be applied without impropriety. In the American debate, Professor Howison, who was the champion of this view, declared that 'the central and real meaning of the Christian religion lies exactly in the fact that the Creator and the creature are reciprocally and equally real, not identical; that there is a Fatherhood of God and brotherhood of man; that God recognises rights in the creature and acknowledges duties towards him ; and that men are accordingly both unreservedly and indestructibly real-both free and immortal.' We can hardly fail to recognise in this last gentence a democratised version of the Ritschlian thesis that the Kingdom of God and the Fatherhood of God are the twin centres of the Christian religion. The connexion of the Ritschlian theology with 'Ethical Individualism' is indeed very close ; for which reason we find Ritschlians, like Herrmann and Harnack, denouncing Mysticism as tending to blur the antithesis between God and man, and as favourable only to the 'Catholic' type of piety. Great as are the services which writers of this school have rendered to theology, it seems almost impossible to find room within their system either for a real Incarnation or for sacramental grace. And the vast number of plain-thinking Christians who, like these theologians, assume that 'persons' are fixed and mutually exclusive units, are involved in the same difficulties, which they can only evade by separating the Incarnation, and the events which followed it, from the rest of experience, and regarding them as unique portents guaranteed by autbority.

On the other side we have, on the same idealistic basis, a revival of more distinctively Greek ways of thinking. The Logos-doctrine again becomes the centre of Christological and even of cosmological theory. Among the more ecclesiastical writers we find increased emphasis on divine immanence, on the idea of the Church as the Body of Christ, on sacraments as symbols and vehicles of this unification, and a complete resuscitation - the more striking because partly unconscious-of the Eckhartian views of human and divine personality. Those with whom the theological interest is subordinate to the philosophical, elaborate theories of psycho-physical parallelism, and of higher and lower centres of consciousness, as has been done by Fechner and Paulsen.

Dr. Moberly's philosophical position is clearly indicated by many statements in this book. The following may serve as specimens : 'All the different abstracts, pushed back far enough, are personal, and the One same Personal: Power, Law, Life, Thought, Love, are ultimately identified in one supreme, and that necessarily a Personal, existence. Now such 


\section{THE JOURNAL OF THEOLOGICAL STUDIES}

Supreme Being cannot be multiplied: it is incapable of a plural; it cannot be a generic term' (p. 83)'. 'I should prefer to avoid, as misleading, any use, in reference to human personality, of any phrase, such as "a distinct centre of being," which might even seem to conceive of it at all otherwise than in its capacity of relation to, and dependence on, God ' (p. 238). The two extracts which follow are pure Neoplatonism. "By "rational faculty" we mean personal capacity of beholding wisdown and truth' (p. 234). 'Its [Reason's] highest ranges are found in fact to be more and more identified with that consummation of the self by its passing beyond itself, in which we have already found the climax of human free-will' (p. 240). Very important, as illustrating Dr. Moberly's fearlessly monistic thought, is the following passage on the consciousness of the human Christ: 'The centre of His life is never in Himself. There is no possibility, even for a moment, of the imagination of separateness; no such thing, we may even say, as a consciousness alone and apart. Those great words "I and the Father are one" are spoken by the Incarnate, the Christ, the Son of Man, in time and in place, and through buman brains and lips-not simply, across infinities, by the Eternal Logos' (p. 99).

Dr. Moberly has supposed that some expressions in his book might cause him to be suspected of Sabellianism; and he has met this charge successfully on pp. $85-6$. Perhaps one may venture to suggest that he might have shown a little more clearly in what way his conception of personality, or of reality, differs from Idealistic Pantheism. There are pages in the book in which the principle of individuality, even as a rela. tive fact, seems to need reinforcement. Perhaps this might be found in teleology. The human individual, while in space and time, is presumably a unique expression of a particular idea or purpose of God, which he and he only can realise. Under this aspect he must be 'distinct,' and even (in a sense) separated, until his task is fulfilled.

The vague and often unmeaning charge of 'Pantheism' is so frequently brought against thinkers of the school to which Dr. Moberly now finds himself (see p. 237, note) approximating, that it would have been interesting to know whether, with Amiel, he regards Idealistic Pantheism as a creed which Christianity must conquer by absorption, or whether he thinks that suoh cosmological applications of the doctrines of the Logos and of the Holy Spirit should be deprecated. The chapter in which we most feel the want of further elucidation on these lines, is that in which the freedom of the will is discussed. Dr. Moberly

1 The references in this and other paragraphs should be verified, because I have found it necessary to omit a few of the frequent parentheses and alternative phrases which characterise Dr. Moberly's rich but very diffuse and homiletic style. The quotations would otherwise have been too long. 
shows, in a beautiful and eloquent passage, that free-will is not an equal choice between alternatives, but 'man's power to do perfectly, and perfectly as his own, that which is his own perfectness, in other words that which reflects God, and is in truth God in him ' (p. 226). But the question remains, Is there a persistent self who is morally responsible for the greater or less distance which at any moment separates him from this ideal? It must be remembered that the pluralist postulates his half-independent monads mainly in order to secure this ethical responsibility. He gives (philosophically) an enormous price for them, but thinks himself repaid if, as Professor Ward boasts, he can 'introduce contingency into the heart of things.' He evidently thinks that monistic philosophy leaves room for only one free-will-that of God-in the universe. And though Dr. Moberly is writing not a treatise on metaphysics but an essay in dogmatic theology, the question whether this conclusion can be avoided does seem to fall within his subject.

The first three chapters, which contain analyses of the three conceptions of Punishment, Penitence, and Forgiveness, are intended to clear the way for a discussion of the Atonement. It is not Dr. Moberly's fault if he fails to reduce to perfect order the chaos in which the first of these three words still welters. Not only is 'Punishment' used in three different senses, to express $(a)$ vindictive infliction of pain, $(b)$ an 'example' intended to frighten potential offenders, $(c)$ a particular method of training character; but, while some moralists declare that vindictive punishment is only worthy of a savage or a demon, others, like Mr. Bradley, insist that it is fundamentally immoral to punish any one for any other reason than because his acts deserve it. It is therefore rather hopeless to analyse the word as if it had one fixed connotation. The chapter on Penitence is difficult, but interesting. The thesis that 'the Atonement is the consummation of Penitence' caused some surprise at Dr. Sanday's Conference, as appears from the published Report ; and some of Dr. Moberly's readers will probably still demur to it. But it is well worth thinking out, with the help of the author's explanations.

In the discussion of the Atonement, which follows, a welcome and noteworthy feature is the emphatic rejection of those 'transactional' theories which since Anselm have dominated Christian thought so unduly, especially in Protestant countries; and the treatment of the office and work of the Holy Spirit is singularly illuminating.

It only remains to say that this attempt to fix Dr. Moberly's philo. sophical position has done no sort of justice to the immense value of his book as a purely religious treatise. There is hardly a page which does not contain some beautiful and stimulating thought, and not a chapter which would not furnish material for excellent University or 
Cathedral sermons. To the thoughtful reader it will suggest many subjects for deep and reverent meditation, which under Dr. Moberly's guidance will often pass into acts of devotion. For this part of the book the critic must be content to express his respectful gratitude. The more speculative part will not, of course, command universal assent; but to the present reviewer, at any rate, it is a matter for unmixed rejoicing that an honoured leader of the most influential school in the English Church should have so definitely committed himself to a type of theology which, I believe, contains the best bope and promise for our Church in the century which has just begun.

W. R. INGE.

\section{THE ABBE LOISY AND BIBLICAL CRITICISM.}

\section{Etudes Bibliques, par Alfred LoISY. (Paris: Alphonse et. Fils, r901.)}

THIs little book consists of six essays, four of which appeared in a somewhat short-lived review, L'enseignement biblique, which lasted only two years (1892-1893), the others in La Reoue du clerge franfais, in 1899 . They have a common object - as the author says, "la conciliation du dogme et de la discipline catholiques avec l'étude scientifique de la Bible.' They consist of an exposition of the principles and some of the leading results of Biblical criticism, put forward with great clearness and reverence for the benefit of the members of his own Church. The Abbé Loisy is one of the ablest and most brilliant of the younger French theologians, and this book is important out of all proportion to its size.

The problem is one the difficulty of which we recognise, for we ourselves bave to face it, and it is an advantage to have it discussed by a member of a Church which naturally has among its members those whose hold of traditional views is very tenacious, and yet is in some ways freer than any other Church to approach the problem. When the grounds of dogmatic belief rest on an authority independent of the Bible, there is, although the members of the Roman Church do not yet seem to have realised it, less need for timidity in dealing with critical views. There is nothing in these views which would in any way interfere with the fundamental truths of Christianity, and what these truths are is declared for members of the Roman Church by an authority which is in a sense at any rate independent of the Bible.

However, we are not concerned with the special purpose of the author, but it is our business to estimate so far as we are able his merits as a critic and a theologian, and we are inclined to rate them very high. We 